\title{
O PROBLEMA DA VINGANÇA PRIVADA (AUTOTUTELA): ENTRE O MINIMALISMO GARANTISTA E O ABOLICIONISMO RADICAL
}

\author{
Ney Menezes de Oliveira Filho ${ }^{1}$ \\ Alessandra R. Mascarenhas Prado ${ }^{2}$
}

\section{RESUMO}

O estudo parte do questionamento sobre a legitimação da pena, considerando os linchamentos praticados no Brasil, a despeito da intervenção crescente do sistema penal. O objetivo é analisar como é tratada a relação entre vingança privada e legitimação da pena nos discursos garantistas e abolicionistas. A metodologia utilizada foi descritiva e exploratória: revisão bibliográfica, para explicitar as principais características das perspectivas teóricas citadas e o tratamento conferido à autotutela/função da pena; e pesquisa empírica sobre situações de linchamento ocorridas em Salvador/BA, fazendo paralelo entre as vinganças pública e privada.

Palavras-chave: vingança privada; linchamento; sistema penal; garantismo; abolicionismo.

\section{THE PROBLEM OF PRIVATE REVENGE: BETWEN THE GARANTIST MINIMALISM AND THE RADICAL ABOLITIONISM}

\begin{abstract}
This study is based on the question about the penalty legitimization, take into consideration the practice of lynching in Brazil, despite the increasing intervention of criminal system. The objective is to analyze the relation between private revenge and the penalty legitimization in the garantist and abolitionist discourses. The methodology used was descriptive and exploratory: bibliographical revision, to explain the main characteristics of the theoretical perspectives mentioned in relation to the private revenge and penalty function; and empirical research on lynching situations, drawing a parallel between public and private revenge.
\end{abstract}

Key-words: private revenge; lynching; criminal system; Garantism; Abolitionism.

\section{Introdução}

A vingança privada consiste, basicamente, em uma forma específica de reação social, onde a vítima busca a satisfação das suas pretensões com os seus próprios meios, como uma possibilidade de autotutela ou autodefesa. Normalmente, associada à barbárie ou a uma prática em uma "terra sem lei", ainda é utilizada como meio de controle social em alguns países, a exemplo do Brasil, escapando à regra do controle social realizado pelo Estado.

\footnotetext{
${ }^{1}$ Mestre, PPGF/UCSAL; Doutorando, PPGD/UFBA. Professor de Direito Penal, Curso de Direito, UNEB. Email: ney1083@gmail.com

${ }^{2}$ Doutora em Direito, PUC/SP; Professora de Direito Penal, Faculdade de Direito e PPGD/UFBA. Email: armprado@yahoo.com.br
} 
Por vezes, no senso comum, reverbera a ideia de que a ausência do Estado, a impunidade ou "leis fracas" seriam o motivo para a realização da vingança privada, o que, em tese, justificaria a existência do controle social penal, a fim de inibir esse tipo de reação informalizada por parte da vítima. No Brasil, apesar da recorrência de situações representativas da autotutela, existe uma dificuldade no estudo sociológico sobre o tema, como aponta Martins (1995).

No âmbito jurídico, além das teorias (fins ou funções) justificacionistas da pena, que parecem oferecer o sustentáculo para a existência e aplicação da reprimenda penal, o receio do retorno à vingança privada também é algo recorrente nos discursos, principalmente daqueles que se baseiam na idéia de prevenção geral (dissuasão), como por exemplo, aquele de cunho garantista, almejando conferir legitimidade e credibilidade ao sistema penal para satisfazer os interesses daquelas pessoas realmente envolvidas no conflito rotulado de "criminal".

Por outro lado, o aumento dos casos de vingança privada no Brasil, como as situações de linchamentos, espancamentos, homicídios praticados em transportes coletivos em suposta reação ao crime de roubo, dentre outras, em um contexto marcado pelo aumento vertiginoso da população carcerária brasileira, provoca o seguinte questionamento: a justificação da pena pode encontrar como fundamento a premissa de que a vingança pública afasta a vingança privada?

Em tese, partindo de premissas legitimadoras sobre a pena, com o aumento da aplicação da pena privativa de liberdade haveria menos espaço para o exercício, por parte das vítimas e/ou familiares, da autotutela. Entretanto, mesmo com uma política de encarceramento de massa por crimes de tráfico e contra o patrimônio, não se observa, no Brasil, a anulação ou inibição dessa forma de lidar com os conflitos. Logo, realizar reflexões iniciais para a compreensão da relação simbiótica entre a vingança pública e a vingança privada pode viabilizar a construção de respostas mais maduras e eficazes de intervenção nos conflitos.

O presente artigo objetiva, então, investigar as especificidades garantistas e abolicionistas na abordagem da vingança privada (autotutela) como legitimação da pena. Trata-se de pesquisa bibliográfica e interdisciplinar que reflete sobre uma relevante premissa de legitimação do sistema de justiça criminal hodierno, qual seja: a noção de que a vingança pública afasta, inibe e/ou controla a vingança privada. 
A análise teórica proposta sobre a vingança privada encontra como ponto de partida dois blocos teóricos: o garantismo penal e o abolicionismo. O primeiro está representado neste trabalho por intermédio das contribuições de Luigi Ferrajoli, no seu livro Direito $e$ Razão; enquanto que o segundo, além de demarcar algum tipo de contraponto, inaugura uma perspectiva mais crítica sobre o sistema de justiça criminal e está apoiado nas contribuições de Louk Hulsman, Nils Christie e Thomas Mathiesen.

Assim, a partir de uma possível análise da vingança privada à luz das perspectivas teóricas eleitas, observa-se uma dificuldade ou esquecimento desse problema nas discussões mais atuais sobre a sustentação da pena e da prisão.

Com a finalidade de atingir o objetivo geral, a pesquisa deve alcançar algumas metas intermediárias, como, por exemplo, explicitar o como garantismo e o abolicionismo realizam a abordagem da vingança privada; discutir como a vingança privada se relaciona com a questão da cifra oculta e do caráter irreal das estatísticas criminais oficiais; e, por fim, estudar a problemática referente à vingança privada com situações de linchamentos ocorridos em Salvador/BA, entre 2016 e o mês de julho de 2017.

Trata-se de pesquisa bibliográfica, interdisciplinar e com viés empírico, uma vez que, mesmo partindo de referencial teórico específico, não negligencia na observação da realidade, utilizando-se, para tanto, de notícias veiculadas em jornal de grande circulação para colher dados sobre os casos de linchamentos ocorridos em Salvador, no intervalo de tempo acima descrito.

A construção da hipótese ocorrerá em consonância com os dados colhidos, oportunizando uma aproximação do tema comprometida com os fatos analisados. A pesquisa também é interdisciplinar, pois se vale de vários ramos do saber, tais como a Criminologia, a sociologia, a filosofia e o direito penal. Como o fenômeno criminal é multifacetário, uma leitura fragmentada colocaria em risco uma análise mais ampla e totalizante da problemática enunciada. Então, o caráter interdisciplinar da pesquisa é uma consequência da complexidade inerente ao objeto de estudo.

\section{O garantismo penal e a questão da vingança privada}

Apesar da tarefa árdua de caracterizar o seu marco inicial e final, observa-se que a história da vingança privada acompanha o desenvolvimento do Estado e a fundação do 
paradigma moderno de ciência. Em uma fase mais enaltecida, também chamada de "idade de ouro", entende-se que a vítima poderia satisfazer as suas pretensões pessoalmente, buscando a reparação do dano ou a retribuição pela lesão sofrida. Além disso, não havia uma individualização do rechaço promovido, o que significa que outras pessoas diferentes do agressor poderiam ser atingidas ${ }^{3}$.

A mudança mais significativa nesse aspecto vem com o Estado moderno, uma vez que se constata a concentração do direito de punir nas mãos do ente público, deslocamento este consubstanciado nas contribuições iluministas. "A resposta pública (pena estatal) aos danos provocados às pessoas pelas agressões e perversidades remanescentes do humano (violências e restos bárbaros), afirmaria de forma categórica a opção da comunidade pela civilização". (CARVALHO, 2011, p. 108)

A tentativa de racionalização do direito de punir representada pelos autores da Escola Clássica (C. Beccaria, F. Carrara e G. Rogmagnosi) ilustra de maneira significativa a necessidade de elaboração de um programa proporcional para o exercício da vingança pública e, ao mesmo tempo, um espaço de contenção das vontades privadas relacionadas às repulsas pelos crimes sofridos.

Ao Estado liberal, portanto, é auferida a responsabilidade de limitar duas formas diversas de agressão, dois distintos desejos (vontades) de violência: violência privada, refletida no dano individual pelo desejo do lupusnaturalis de gozar de bens (materiais e imateriais) inacessíveis pela sua escassez ou decorrentes do excesso passional introduzido na reação às agressões ilegítimas (justiça privada); violência pública, verificável no abuso de poder (vontade de punição) das agências repressivas do lupusartificialis quando dos exercícios legítimos (Weber) ou ilegítimos (Direito Penal Subterrâneo ou do Terror) das violências. (CARVALHO, 2011, p. 108).

Embora se perceba significativa discrepância no que concerne à separação entre direito e moral, bem como entre outros variados aspectos, observa-se que a teoria do garantismo penal encontra similitudes com o pensamento liberal moderno, principalmente quando se mostra adepta de um minimalismo penal, da proporcionalidade das penas e, sobretudo, do receio da vingança privada, sendo este objeto central do presente artigo.

Luigi Ferrajoli (2002, p. 274), em diversas passagens de sua obra Direito e Razão, enfrenta a problemática da autotutela, erigindo-a mesmo como fundamento do direito de punir, na medida em que:

\footnotetext{
${ }^{3}$ Segundo Luigi Ferrajoli (2002, p. 231), "A 'vingança de sangue' não era em absoluto una reação instintiva ou espontânea. Era, pelo contrário, um direito e, ainda antes, um dever que recaía sobre a parte ofendida e seu grupo de parentesco. E dirigia-se também, solidariamente, contra o ofensor e seu grupo de parentesco. Sobre a vingança de sangue, e mais em geral sobre a vingança privada como forma originária de punição na maior parte das sociedades primitivas $[\ldots] "$.
} 
O duplo objetivo do direito penal, já dissemos, é a prevenção quer dos delitos, quer das reações informais a ele. Este segundo objetivo, por sua vez, se articula em duas finalidades, quais sejam a prevenção geral da vingança privada, individual e coletiva, tal como expressa na vingança de sangue, no exercício das próprias razões, no linchamento, na represália e outros similares, e a prevenção geral da vingança pública, que, na ausência do direito penal, seria atuada por poderes soberanos de tipo absoluto e despótico, não regulados nem limitados por normas e garantias.

O autor italiano entende que a prevenção geral de delitos e das reações particulares aos crimes, além do impedimento de excessos pelo arbítrio punitivo estatal, são as metas principais do direito penal. Então, para Ferrajoli, a história do direito penal está entrelaçada com o deslocamento do exercício do direito de punir para o Estado, contemplando uma necessidade de prevenção, tanto das condutas particulares diante dos atos lesivos, como do Estado na aplicação de sanções penais. Essa dupla face preventiva faz com que o garantismo penal seja considerado como um fim em si mesmo (ANDRADE, 2012, p. 268) ${ }^{4}$, já que a cogitação sobre a contração máxima do sistema penal traria consigo uma possibilidade de retorno à selvageria.

Também em sua obra, Principia iuris: Teoría del derecho y de la democracia (volumes 1 e 2), conforme analisa Gustavo Noronha (2016, p. 550), Ferrajoli “deixa claro que o direito penal é a única alternativa à guerra", considerando que:

o "princípio da paz" seria o justificador de todo o Direito Penal, no seguinte sentido trabalha sua necessidade: "para alcançar a exclusão da força e, portanto, da violência, a não ser quando o uso dessa força esteja juridicamente previsto e regulado como alternativa a maior violência que se produziria se não existisse".

Ao tratar da problemática referente à vingança privada e ao abolicionismo, Zaffaroni (2001, p. 103) destaca que o autor italiano entende a perspectiva abolicionista como uma verdadeira "utopia regressiva", pois representa uma vulnerabilização dos desviantes, em razão da ausência do Direito Penal e dos limites que ele traz consigo; e, por conseguinte, uma potencialização das reações informais para os não-desviantes, o que poderia ensejar uma anarquia punitiva.

Em apertada síntese, afirma-se que a problemática da vingança privada, no pensamento de Luigi Ferrajoli, aparece atrelada ao objetivo do Direito Penal e, ao mesmo tempo, como óbice ao abolicionismo penal. Em uma perspectiva imediata, o garantismo penal aparece como proposta teórica que contempla uma necessidade evidente de proporcionar

\footnotetext{
4“"Enquanto o abolicionismo põe em relevo os custos do sistema penal, o Direito Penal mínimo de Ferrajoli centra-se nos custos potenciais de uma anarquia punitiva, sustentando que o Direito penal mínimo estaria legitimado pela necessidade de proteger, a um só tempo, as garantias dos "desviantes" e dos "não-desviantes". (ANDRADE, 2012, p. 268)
}

Revista de Criminologias e Políticas Criminais | e-ISSN: 2526-0065 | Salvador | v. 4 | n. 1 | p. 61 - 81 | 
validade e vigência aos direitos fundamentais, por intermédio do sistema de garantias $(S G)$, a partir, sobretudo, da legitimação interna, viabilizando parâmetros normativos intrassistêmicos aptos, em um campo teórico, no sentido de minimizar a atividade punitiva estatal.

Ainda no que condiz à polêmica entre a questão da vingança privada e o abolicionismo no pensamento de Ferrajoli, Salo de Carvalho (2011, p. 125) indica que a teoria do autor italiano:

[...] exclui os projetos abolicionistas sustentando a possibilidade de, na ausência da resposta estatal ao crime (pena criminal), os grupos sociais retomarem práticas précivilizadas de retaliação como exercício arbitrário das próprias razões ou adotarem medidas de controle tecnológico totalitárias formatando sociedades de vigilância disciplinar.

Nesse sentido, Ferrajoli (2002, p. 270) expressamente declara que "A lei penal é voltada a minimizar esta dupla violência, prevenindo, através da sua parte proibitiva, o exercício das próprias razões que o delito expressa, e, mediante a sua parte punitiva, o exercício das próprias razões que a vingança e outras possíveis reações informais expressam”.

A partir de tais considerações, torna-se importante perceber como o garantismo penal acaba relegitimando o Direito Penal, pois reúne esforços no sentido de justificar o sistema penal, ao configurá-lo como um sistema de minimização das violências na sociedade.

Embora existam essas digressões no campo teórico, "no campo da prática, no entanto, abolicionismos e minimalismos oferecem ferramentas de trabalho convergentes e preciosíssimas para serem apropriadas cotidianamente na prática do sistema" (ANDRADE, 2012 , p. 268) ${ }^{5}$. Tendo em vista essa aparente oposição entre abolicionismo e garantismo, Vera Regina parte da premissa de que é relevante buscar zonas de intersecção entre o abolicionismo e os minimalismos.

Diante dessa discussão, apresenta-se como pertinente algum tipo de questionamento acerca do cumprimento dos objetivos eleitos por Ferrajoli para o Direito Penal. Sabe-se que a preocupação do autor não é oportunizar uma crítica aprofundada dos fundamentos do direito de punir. Ainda que o autor admita como utópica a possibilidade de máxima efetividade do sistema de garantias, não se pode olvidar que, distante de uma constatação empírica, a eleição de tais metas justificacionistas podem ser objeto de problematização.

\footnotetext{
${ }^{5}$ Ainda segundo a autora, "Enquanto o abolicionismo põe em relevo os custos do sistema penal, o Direito Penal mínimo de Ferrajoli centra-se nos custos potenciais de uma anarquia punitiva, sustentando que o Direito penal mínimo estaria legitimado pela necessidade de proteger, a um só tempo, as garantias dos "desviantes" e dos "não-desviantes". (ANDRADE, 2012, p. 268).
} 


\section{O abolicionismo penal e a questão da vingança privada}

O abolicionismo, na área penal, é caracterizado pela heterogeneidade do discurso, tendo em vista que decorre de plúrimas abordagens críticas sobre a prisão, o Direito Penal e o sistema de justiça criminal. São destacados como principais representantes do abolicionismo Thomas Mathiesen, Nils Christie e Louk Hulsman.

De maneira contrária ao minimalismo garantista, o abolicionismo não justifica a pena na necessidade de prevenção da violência estatal, nem tampouco na imprescindibilidade de evitar a reação informal dos ofendidos. A premissa abolicionista sobre a vingança privada reside mesmo em uma variante epistemológica, uma vez que não define o Direito Penal a partir das suas funções declaradas, mas sim dos seus objetivos ocultos ou latentes.

Sendo assim, seria o próprio sistema de justiça criminal, reprodutor e legitimador de assimetrias sociais, aquele responsável também pelo incremento da violência, o que desafia de maneira flagrante o pensamento garantista. Ainda que Ferrajoli entenda o abolicionismo como uma "utopia regressiva", conforme fora analisado alhures, há que se problematizar sobre a potencialidade da dupla função atribuída ao Direito Penal. Sabe-se da importância da obra do autor italiano para o desenvolvimento de estratégias de contenção do Direito Penal. No entanto, não se pode desprezar também a potencialidade dessa perspectiva no sentido de renovar um sistema de justiça criminal que representa mais dor e sofrimento para os seus clientes.

Diante disso, nesse trabalho, a premissa abolicionista principal sobre a vingança privada é aquela colocada por Hulsman e Celis (1997, p. 114), no seguinte sentido:

\footnotetext{
Alguns dizem que o sistema penal substitui a vingança privada e que esta ressurgiria se ele desaparecesse. Ocorre que o renascimento das milícias e justiças privadas, agindo sob a forma de autodefesa punitiva, se dá precisamente em contextos onde o sistema penal funciona a todo vapor. Não há qualquer razão para se pensar que tal fenômeno se ampliaria se se descriminalizassem, total ou parcialmente, os comportamentos indesejáveis.
}

Para os autores, não seria a vingança pública aquela substitutiva da vingança privada. Pelo contrário, o excesso de controle social formal traduziria um tipo de sociedade capaz de assimilar a cultura punitiva e exercê-la, de per si, em nome do Estado e para o Estado.

Em função disso, entra em cena a ineficácia e a falta de credibilidade do sistema de justiça criminal para satisfazer as pretensões das partes em conflito, como também não se pode negligenciar o fato de que alguns delitos - como aqueles contra a dignidade sexual - 
trazem uma forte marca da revitimização (vitimização secundária), o que significa que os agentes estatais não estão preparados para lidar com a oitiva e o acolhimento dos ofendidos, duplicando a violência e, em muitos casos, reproduzindo desigualdades estruturais dentro do aparato de justiça criminal.

Mathiesen (1997, p. 95) alerta: “A prisão é um sistema profundamente irracional em termos de seus próprios objetivos estabelecidos. Entretanto, a dificuldade é que este seu conhecimento, em grande parte, é secreto".

A partir dessas contribuições, infere-se que o binário finalístico do Direito Penal, em uma abordagem garantista, não prospera, pois, no lugar de cumprir as metas disseminadas culturalmente, o sistema de justiça criminal acaba produzindo mais dor e sofrimento, além daqueles já causados pelo conflito. Daí o questionamento formulado por Hulsman e Celis (1997, p. 114):

Se se mostrasse às vítimas e às pessoas que temem a vitimização que vias diferentes da penal lhes seriam muito mais convenientes; se elas percebessem que, longe de se desinteressar de sua sorte, os que desejam ver desaparecer o sistema penal, na verdade, se interessam mais e melhor, propondo uma forma mais eficaz de tratar seu problema, muitas não renunciariam àquela reação tão nociva quanto estéril?.

O sistema de justiça criminal incrementa na dor e no sofrimento das pessoas envolvidas no conflito, razão pela qual, segundo Nils Christie, não há uma naturalidade ou possibilidade de aceitação irrefletida dessa violência (re)produzida pela privação de liberdade. Assevera o autor que:

[...] eu não posso imaginar uma situação na qual deveria lutar por um aumento da dor infligida pelo homem na terra. Também não consigo enxergar nenhuma boa razão para acreditar que o nível recente de causação da dor é correto ou natural. [...] Não vejo outra posição defensável que não seja lutar por reduzir a dor. Uma das regras seria então: na dúvida, não cause dor. Outra regra seria possível: inflija o mínimo de dor possível. Procure alternativas à pena, não somente penas alternativas. (CHRISTIE, 2017, p. 25)

Nils Christie coloca questão importante para a nossa problematização, qual seja: a dor e o sofrimento gerados pelo sistema penal compensam o risco da vingança privada, que ressurgiria com o abandono da justiça penal? Essa é uma questão que merece atenção especial no sentido de sopesar as (des)vantagens de manutenção do Direito Penal. Eis o tipo de pergunta que exige reflexão mais aprofundada, diante da complexidade necessidade de encontrar elementos empíricos para averiguar a (in)dispensabilidade do cárcere.

Se o abolicionismo penal parece uma medida drástica para colocar fim à inflição consciente de dor causada pela prisão, também se mostra incoerente a continuidade de um 
modelo seletivo, arbitrário e discriminatório de resolução de conflitos. Mesmo que a vingança pública consiga inibir, em algum sentido, a vingança privada, não se tem a real noção dessa premissa, e dois são os motivos indissociáveis pelos quais ela parece incerta, quais sejam: a) a cifra oculta da criminalidade; e, b) o caráter irreal das estatísticas criminais.

Se a criminalização efetiva é um evento raro e excepcional, como sinalizam Hulsman e Celis (1997, p. 66), então muitas condutas desviadas não se transformam em crimes porque sequer chegam ao conhecimento das autoridades competentes. Como a cifra oculta é altíssima, não se tem uma real compreensão também do número total de crimes praticados. $\mathrm{Na}$ verdade, caso as pessoas realmente soubessem da capacidade do sistema de justiça criminal para intervir no número total de condutas desviadas, a sua falência seria tão flagrante que a necessidade de encontrar outras respostas para esse conflito apareceria como algo imprescindível.

Como achar normal um sistema que só intervém na vida social de maneira tão marginal, estatisticamente tão desprezível? Todos os princípios ou valores sobre os quais tal sistema se apóia (a igualdade dos cidadãos, a segurança, o direito à justiça, etc...) são radicalmente deturpados, na medida em que só se aplicam àquele número ínfimo de situações que são os casos registrados. (HULSMAN; CELIS, 1997, p. 66)

A problematização da vingança privada à luz da cifra oculta confere pistas no sentido de deslocar a discussão sobre a justificação do Direito Penal da prevenção das reações informais (autotutela) à impossibilidade real do sistema em administrar o número total de eventos criminalizáveis. Se o sistema não é criado para intervir regularmente nos fatos praticados, então ele é o próprio gerador da cifra oculta e, por consequência, do sentimento de impunidade.

O próximo tópico cumpre o objetivo de enfrentar a questão da cifra oculta, oferecendo o suporte para uma reflexão mais perspicaz sobre a vingança privada.

\section{O problema da cifra oculta e o caráter irreal das estatísticas criminais oficiais}

A criminologia moderna, conforme aduz Molina e Gomes (2012, p.30), é marcada pela ampliação dos seus objetos de estudo. Isso significa que, em sua gênese científica, a criminologia tradicional (também chamada de positivista ou etiológica) concentrava os seus esforços em torno do crime e do criminoso, principalmente quando se tem em perspectiva a antropologia criminal de Cesare Lombroso e a Sociologia Criminal de Ferri. 
A primeira alternativa teórica ao biologismo lombrosiano reside na obra de Émile Durkheim, As regras do método sociológico, publicado no ano de 1895 . Conforme sinaliza Alessandro Baratta (2002), o estrutural-funcionalismo durkheiminiano coloca em dúvida o princípio do bem e do mal, muito representativo do pensamento etiológico. Então, apesar da repercussão ainda hoje no senso comum, a compreensão ontológica do crime, a ideia de investigar o crime na pessoa do infrator, não prospera por tanto tempo na academia.

Outro passo importante na história do pensamento criminológico foi o labelling approach (também chamado de teoria do etiquetamento), influenciado pela etnometodologia e pelo interacionismo simbólico da Escola de Chicago, na década de 30. Segundo essa concepção, o crime em si é o resultado de complexos processos de atribuição de rótulos e etiquetas, indicando "uma abordagem alternativa cujas raízes remontavam ao famoso dito de W.I. Thomas: Se os homens definem situações como reais, elas são reais nas suas consequências". (BECKER, 2008, p. 12)

\footnotetext{
Modelado pelo interacionismo simbólico e o construtivismo social como esquema explicativo da conduta humana, o labellingparte dos conceitos de "conduta desviada" e "reação social", como termos reciprocamente interdependentes, para formular sua tese central: a de que o desvio - e a criminalidade - não é uma qualidade intrínseca da conduta ou uma entidade ontológica preconstituída à reação (ou controle) social, mas uma qualidade (etiqueta) atribuída a determinados sujeitos através de complexos processos de interação social; isto é, de processos formais e informais de definição e seleção. (ANDRADE, 2003, p. 205)
}

Aos poucos, constata-se que a criminologia desloca a sua atividade cognitiva do criminoso para os processos de criminalização, consoante aduz Vera Regina. A contribuição do labelling approach foi fundamental para a virada sociológica (ou epistemológica) operada na disciplina na década de 60, oportunidade em que se instaura um diferente paradigma criminológico. O paradigma da reação social configura uma leitura do fenômeno criminal desconcentrada das causas da desviação primária, introduzindo uma preocupação acentuada nos processos de criminalização.

O paradigma da reação social permite a ampliação dos objetos de estudo da Criminologia, razão pela qual, a vítima e o controle social ganham o protagonismo nas investigações, o que não se observava com o paradigma causal-explicativo (etiológico), uma vez que este estava demasiadamente concentrado na figura do infrator. Essa ampliação do rol de objetos de estudo fez com que se percebesse algo fulcral para as investigações atuais do fenômeno criminal:

Se a conduta criminal é majoritária e ubíqua e a clientela do sistema penal é composta, "regularmente", em todos os lugares do mundo, por pessoas pertencentes 
aos mais baixos estratos sociais, isto indica que há um processo de seleção de pessoas, dentro da população total, às quais se qualifica como criminosos. (ANDRADE, 1996, p. 278)

Em consonância com o que escreve Baratta (2002), o princípio da igualdade resta prejudicado diante da irreversível constatação sobre a seletividade estigmatizante. A percepção inaugurada pelo labelling approach ampliou os objetos de estudo da Criminologia, viabilizando uma investigação mais aprofundada acerca do controle social e da vítima. Tal ampliação permitiu a inserção de outras discussões, principalmente sobre a cifra oculta da criminalidade, o caráter irreal das estatísticas criminais oficiais e a criminalidade de colarinho branco, uma vez que:

Desde o ponto de vista das definições legais, a criminalidade se manifesta como o comportamento da maioria, antes que de uma minoria desviada da população (neste sentido, olabelling approach tem em conta os estudos sobre as infrações não perseguidas, sobre a cifra obscura da criminalidade e a criminalidade de colarinho branco. (ANDRADE, 2003, p. 201)

Então, tendo por base o paradigma da reação social, se o comportamento desviado é a regra, por consequência, tem-se em consideração que muitas condutas criminalizáveis são praticadas, mas poucas chegam ao conhecimento das autoridades competentes. A problemática da cifra oculta da criminalidade revela que o Direito Penal consegue intervir, efetivamente, em uma ínfima parcela das condutas desviadas, razão pela qual a impunidade seria a regra, e não a exceção.

Daí resulta uma pergunta importante: se todos os dias muitas condutas desviadas - a maior parte delas - são praticadas e lidadas sem a intervenção do Direito Penal, não seria plausível cogitar que a menor parte das condutas desviadas fosse também objeto de uma não intervenção do Direito Penal?

Alguns estudos apresentam respostas afirmativas, a exemplo do que Gustavo Noronha de Ávila (2016, p. 557) conclui: "não é possível ignorar que, de certo modo, um abolicionismo já existe, isto porque a regra é o fato de as condutas não serem criminalizadas, não o contrário (recorde-se aqui o impressionante quadro de cifra oculta no tocante ao crime de homicídio)".

Quando se coloca a prevenção da vingança privada como objetivo do Direito Penal, há que se considerar, ao menos como uma ressalva, os problemas que o estudo da cifra oculta da criminalidade pode acarretar, principalmente se as estimativas publicadas forem realmente observadas. Hulsman (1997, p. 65) atenta que, em "uma pesquisa realizada numa empresa de Friburg na Alemanha”, “de 800 fatos acontecidos dentro daquela empresa e que poderiam ter 
sido criminalizados, somente um o foi”. Vera Regina Pereira de Andrade (2012, p. 139) arremata:

\begin{abstract}
Considerando, enfim, que o sistema penal está estruturalmente dedicado "a administrar uma reduzidíssima porcentagem das infrações, seguramente inferior a $10 \%$ ", concluo não apenas que "os processos de imunização constituem a interface negativa dos processos de criminalização", mas que imunidade e impunidade constituem a regra de funcionamento do sistema penal e não a sua disfunção.
\end{abstract}

Se o percentual de intervenção penal é pouco significativo quando comparado ao número total de condutas desviadas, talvez seja possível afirmar que já se tem, dentro da própria dinâmica seletiva do sistema de justiça criminal, um abolicionismo oculto, não declarado. Esse abolicionismo traduzido na ideia de imunização (oposto da criminalização) não nos remete a uma utopia, mas, ao contrário, algo que pode ser confirmado para determinados crimes (ou pessoas que praticam esses crimes), como, por exemplo, casa de prostituição, aborto, crimes contra a ordem tributária, crimes ambientais, crimes contra a administração pública e crimes contra a dignidade sexual (ANDRADE, 2012, p. 152) . $^{6}$

A cifra oculta da criminalidade não compromete apenas a imprescindibilidade da solução penal, mas desafia também a própria produção de dados sobre os conflitos apresentados ao sistema penal. Isso significa que, com os números divulgados, não se tem uma real dimensão das condutas desviadas praticadas. Se as pessoas, em geral, já ficam assustadas com a ideia de impunidade, caso soubessem do número total de eventos criminalizáveis o resultado seria devastador; tanto para o próprio sistema de justiça criminal, que revelaria a sua inaptidão para cumprir as suas promessas; como para a vida das pessoas, pois estariam mais insatisfeitas ainda com a resposta simplista e artificial traduzida no binômio crime/pena.

\title{
5. A cifra oculta da vingança privada e a (in)sustentabilidade da vingança pública
}

Algumas pistas (provisórias) acerca da fragilidade existente na premissa de que a vingança pública afasta (ou controla) a vingança privada serão analisadas a seguir. Inicialmente, a título de ilustração, por intermédio do sistema de busca Google, pesquisou-se

\footnotetext{
${ }^{6}$ Vera Regina Pereira de Andrade destaca que "A regra, na conduta do estupro - seguindo a lógica do sistema -, é a impunidade e a condenação em casos limites, permanecendo aquém da imunidade, pois, seguindo também a lógica de funcionamento do sistema, subsiste uma enorme cifra oculta da violência sexual, especialmente a doméstica, mesmo após a publicização do problema pelo feminismo, bem como a criação das "Casas e Delegacias de Mulheres". (ANDRADE, 2012, p. 152).
}

Revista de Criminologias e Políticas Criminais | e-ISSN: 2526-0065 | Salvador | v. 4 | n. 1 | p. 61 - 81 | 
pelos linchamentos ocorridos em Salvador/BA, entre 2016 e julho de 2017, em publicações do Jornal Correio da Bahia.

O referido jornal foi escolhido como fonte de busca porque demonstrou, no intervalo de tempo designado para a pesquisa, uma maior preocupação com o tema. Além disso, as notícias inventariadas trazem elementos que merecem algumas considerações particulares, como será aqui explicitado.

O objeto de estudo "linchamento" foi escolhido em razão da sua vinculação à problemática da vingança privada. Duas hipóteses principais podem ser cogitadas: a) a vingança pública inibe a vingança privada e, em função disso, mesmo com muitos casos de autotutela, há que se observar um controle ou inibição desses casos; b) a vingança pública, no lugar de inibir a vingança privada, traduziria a representação de um comportamento estatal violento, contaminando não apenas aqueles atingidos pelo sistema penal, como também os demais cidadãos.

Esta segunda hipótese traria importantes desdobramentos, como, por exemplo, a análise de assimilação da violência pública pelo corpo social, a coincidência (ou não) do alvo da vingança pública como o alvo da vingança privada, o tipo de crime perseguido pela vingança pública e pela vingança privada, dentre outros aspectos que poderiam ser desenvolvidos e analisados com maior perspicácia. No entanto, diante do curto desenvolvimento, este ainda não é o espaço de cumprir esses desdobramentos, o que pode ser realizado em investigações posteriores.

Sendo assim, como o presente trabalho configura uma aproximação com pistas iniciais sobre a temática, pode ser necessário, a partir deste esforço, aprofundar a pesquisa para se chegar a uma percepção mais conclusiva.

Passadas as ressalvas metodológicas iniciais, cumpre-se, nas próximas linhas, a análise das notícias colhidas.

A reportagem do dia 04/07/2017, de autoria de Thais Borges (2017), sinaliza para o fato de que:

[...] um levantamento realizado pelo correio nos mostrou que a Bahia registrou pelo menos 45 casos de linchamentos ou tentativa de linchamento de 2016 até julho deste ano - desses, 32 foram em Salvador O número não destoa da realidade do Brasil tido por especialistas como o país que mais comete linchamentos no mundo. Há, pelo menos, um linchamento ou tentativa por dia. E Salvador se destaca entre as cidades que mais têm esse sangue nas mãos. 
Categoricamente, não se pode afirmar que o número de casos de vingança privada tem aumentado ou diminuído. Muitas são as dificuldades encontradas para se investigar essa temática. Conforme sinaliza José de Souza Martins (2017), “[...] também o pesquisador tem poucas possibilidades de localizar informantes que lhe permitam reconstituir o acontecimento com o cuidado que desejaria".

As dificuldades decorrem, basicamente, de dois fatos: a) as pessoas que participam desses eventos não são identificadas, mesmo naquelas situações com resultados mais gravosos; b) não existe tanto interesse das autoridades competentes na investigação desses atos de violência, o que pode estar relacionado com o fato de que o linchamento, muitas vezes, tem como precedente uma conduta considerada como criminosa.

Em notícia publicada no dia 28/05/2016, com o título Homem morre após ser espancado e baleado no Engenho Velho da Federação, sem autoria definida, observa-se que morador do referido bairro foi atacado por oito homens, sendo alvejado por tiros e agredido fisicamente. O final da reportagem consigna que "ainda não há informações sobre a motivação do crime. O caso será investigado pelo Departamento de Homicídios e Proteção à Pessoa" (REDAÇÃO, 2017). Além disso, apesar da presença da polícia, nenhum suspeito foi encontrado no local.

Em matéria publicada no dia 04/07/2017, cujo título era Polícia resgata vítimas de tentativas de linchamentos em $90 \%$ das vezes; conheça os casos, de autoria de Thais Borges, destaca-se o seguinte: "procurada pelo CORREIO, a PM não soube informar quantos chamados recebeu desde 2016 para atender situações do tipo. Já a Secretaria da Segurança Pública do Estado (SSP-BA) afirmou que não contabiliza esses chamados” (BORGES, 2017).

Outra matéria de título Após matar duas pessoas, homem é linchado em festa na Bahia, publicada pela redação do jornal no dia 03/04/2016, destaca-se que "A PM não soube informar a autoria do crime" (REDAÇÃO, 2016).

Todos esses fatos descritos apontam para as dificuldades acima ilustradas, ou seja, os autores desses eventos lesivos, em regra, não são identificados e, além disso, mesmo quando esses acontecimentos são contabilizados pelas autoridades competentes, não há um maior interesse em encontrar essas pessoas. Tudo isso remete a uma cifra oculta da vingança privada, para os casos que não são computados pelas autoridades competentes, e/ou uma ocultação da cifra real, já que aqueles casos que chegam às autoridades competentes não são levados adiante. 
É realmente inusitado que isso ocorra em um estado que investe muito em controle social formal (MOLINA; GOMES, 2012, p. 128) ${ }^{7}$, principalmente na contratação de novos policiais militares. Nesse sentido, seria importante outra pesquisa a fim de analisar a redução concreta de crimes diante da presença da polícia ou mesmo do aumento do efetivo policial em determinados bairros de Salvador. Por ora, constata-se apenas que o incremento do controle social formal, sob o manto do discurso punitivista, não consegue, por si só, evitar situações de autotutela, nem é efetivamente programado para cumprir essa tarefa, que no discurso garantista aparece como objetivo do Direito Penal.

Então, a insuficiência da vingança pública para administrar as situações de vingança privada pode traduzir, em verdade, que elas, no lugar de ocuparem posições paradoxais como comumente é colocado - estão necessariamente imbricadas. Os aspectos que denunciam, em uma primeira leitura, a aproximação entre a vingança pública e a autotutela são: a construção social dos linchados como correspondente ao estereótipo do criminoso comum e, principalmente, os fatos perseguidos pelo sistema penal e a coincidência com os fatos que ensejam situações de linchamento (estupros, furtos, roubos e homicídios).

No que concerne ao primeiro aspecto, na tarefa de construção social da criminalidade, constata-se a existência de uma criminalização primária, isto é, aquela caracterizada, segundo Vera Regina (1999, p. 26), pela “definição legal de crimes pelo Legislativo, que atribui à conduta o caráter criminal, definindo-a (e, com ela, o bem jurídico a ser protegido) e apenando-a qualitativamente e quantitativamente"; como também da criminalização secundária, ou seja, aquela "seleção de pessoas que serão etiquetadas, num continuum pela Polícia-Ministério Público e Justiça”. A ideia de estigmatização como marca indelével deixada no sujeito encarcerado aparece como criminalização terciária.

As agências formais de controle social não apenas fazem o rastreamento isento dos eventos criminalizáveis, mas participam de maneira decisiva da construção da criminalidade e, em razão disso, pode-se afirmar que:

O controle social, por isso, não se limita a "detectar" a criminalidade e a identificar o infrator, mas antes "cria" ou "configura" a criminalidade: realiza uma função "constitutiva", de sorte que nem a lei é expressão dos interesses gerais nem o processo de sua aplicação à realidade respeita o dogma da igualdade dos cidadãos. Os agentes do controle social formal não são meras correias de transmissão da

\footnotetext{
${ }^{7}$ Segundo os autores, “O controle social penal tem limitações estruturais inerentes à sua própria natureza e função, de modo que não é possível exacerbar indefinidamente sua efetividade para melhorar, de forma progressiva, seu rendimento. A prevenção eficaz do crime não deve se limitar ao aperfeiçoamento das estratégias e mecanismos de controle social. Com razão dizia Jeffery: 'mais leis, mais penas, mais policiais, mais juízes, mais prisões significam mais presos, porém não necessariamente menos delitos””. (2012, p. 128)
} 
vontade geral senão filtros a serviço de uma sociedade desigual que, por meio deles, perpetua suas estruturas de dominação e incrementa as injustiças que a caracterizam. (MOLINA; GOMES, 2012, p. 126)

Todos esses fatores corroboram a ideia de que se a vingança pública é exercitada a partir do estereótipo do criminoso comum - o que não acontece no caso da criminalidade de colarinho branco (BARATTA, 2002, p. 102) ${ }^{8}$. Não apenas a dinâmica da criminalização oficial, com as consequências da criminalização secundária, configura parte do processo social necessário para a vingança pública, mas a própria vingança privada se vale do mesmo estereótipo.

Em publicação do dia 04/07/2017, a jornalista Thais Borges (2017) comenta uma situação de linchamento, ocorrida em novembro de 2016, no bairro de São Caetano:

As imagens correram pelos celulares. Vídeos e fotos exibiam, sem qualquer aviso, um jovem negro ser espancado e receber golpes de enxada de um grupo de pessoas. Às partes do corpo sem vida, atearam foto. E, para completar a sequência de horror, carregaram, em um carrinho de mão, o que restou do rapaz. Despejaram em frente à Creche Escola Menino de Jesus, no Arenoso.

O sistema penal promove um critério de seleção e segregação das pessoas integrantes de determinadas estratificações sociais. As etiquetas não incidem de uma maneira uniforme em todos os setores sociais e o etiquetamento depende também do acesso e utilização dos recursos hábeis para não ingressar no ambiente carcerário. O cometimento de delitos ocorre em todas as estratificações sociais, mas os mecanismos de controle são mais eficazes nas classes menos favorecidas. Por conta disso, afirma-se que o Direito Penal ao revés de punir condutas, acaba por selecionar pessoas, como expressam Zaffaroni e Pierangelli (2001, p. 70):

Com efeito: "punição" é uma ação e efeito sancionatório que pretende responder a outra conduta, ainda que nem sempre a conduta a que responde seja uma conduta prevista na lei penal, podendo ser ações que denotem qualidades pessoais, posto que o sistema penal, dada sua seletividade, parece indicar mais qualidades pessoais do que ações, porque a ação filtradora o leva a funcionar desta maneira. Na realidade, em que pese o discurso jurídico, o sistema penal se dirige quase sempre contra certas pessoas mais que contra certas ações.

A exclusão da figura do outro a partir das definições que lhe são imputadas ocasiona a perpetuação de um saber penal discriminatório, ou seja, de acordo com os conceitos distribuídos e aceitos no convívio social, há uma reprodução constante de determinados

\footnotetext{
${ }^{8}$ Tais fatores, conforme BARATTA (2002, p. 102) "são ou de natureza social (o prestígio dos autores das infrações, o escasso efeito estigmatizante das sanções aplicadas, a ausência de um estereótipo que oriente as agências oficiais na perseguição das infrações, como existe, ao contrário, para as infrações típicas dos estratos mais desfavorecidos), ou de natureza jurídico-formal ( a competência de comissões especiais, ao lado da competência de órgãos ordinários, para certas formas de infrações, em certas sociedades, ou, ainda, de natureza econômica (a possibilidade de recorrer a advogados de renomado prestígio, ou de exercer pressões sobre os denunciantes etc.)".
} 
critérios que identificam aqueles mais vulneráveis à incidência das instâncias de controle social. A ausência de empatia é intrínseca e funcional ao próprio saber penal dominante, razão pela qual é insurgente a segregação decorrente dos seus mecanismos de seleção.

Sendo assim, o saber penal discriminatório não está presente apenas nos casos de vingança pública, mas se estende também às situações de vingança privada, pois as pessoas e os delitos, que geralmente aparecem como objetos de linchamentos, são os mesmos eleitos pelo controle social formal como objeto de perseguição. Pesquisas posteriores podem evidenciar uma cultura punitiva interseccionada tanto na vingança pública quanto na autotutela, o que significa que uma não anula a outra, mas pode incrementar na certeza da reação violenta popular diante do fato observado.

Tal ausência de alteridade é consequência também do paradigma criminológico positivista, posto que aquele que possui o poder de definição, no caso concreto, rotula o objeto cognoscível como "mal" (noção de maniqueísmo). Há uma espécie de fetiche no processo de configuração da identidade criminosa, pois as etiquetas encontram os seus objetos a partir de parâmetros (procedimentos) prévios que denunciam a caracterização do "mal" a ser combatido, simbolicamente representado. Os linchamentos acabam reproduzindo essa dinâmica.

Essa seleção dos linchados como correspondente ao estereótipo do perseguido pelo sistema penal inaugura também, diante da ineficácia do sistema legal, a possibilidade de autotutela. Como o Estado é mais incisivo na perseguição de alguns delitos, o que impede a reação informal e particular diante dos mesmos casos?

Especula-se que a vingança privada afaste a vingança pública, mas é possível observar algumas pistas no sentido de que pode existir uma relação muito mais de influência entre uma e outra do que, inexoravelmente, controle, restrição ou inibição. A partir das notícias analisadas, pode-se afirmar que a cifra oculta, por um lado, impede que o discurso garantista possa constatar veracidade na sua premissa (a vingança pública afasta a vingança privada); por outro lado, o abolicionismo não poderia, sem uma pesquisa mais cuidadosa, afirmar que a vingança privada é estimulada pela vingança pública.

A problemática da vingança privada, geralmente colocada como óbice ao abolicionismo, não parece subsistir aos fatos que traduzem a autotutela. Tem-se, de maneira corriqueira, notícias de reações a assaltos em transportes coletivos, execuções de pessoas por 
crimes perseguidos demasiadamente pelo sistema penal e, sobretudo, a constatação de um interesse individualizado (nos crimes contra o patrimônio e contra a dignidade sexual).

A discussão de gênero feita por Vera Regina, em relação aos crimes contra a dignidade sexual, indica que a sociedade androcêntrica ensina o sujeito a compreender a mulher como coisa, o que denuncia uma assimetria social que corresponde ao sexismo denunciado pela autora.

Sobre os linchamentos, observa-se também algum tipo de assimetria pela transformação do outro em coisa, pela ausência de alteridade e empatia. Essa rotinização da compreensão sobre o fenômeno criminal é alimentada muitas vezes pelo próprio sistema penal, que coloca para estupradores penas que não estão escritas em lugar algum. Esse código marginal, mas presente na realidade das prisões, é assimilado pela cultura punitivista, não apenas no cárcere, impedindo a construção de perspectivas mais satisfatórias para a resolução dessas situações e incrementando na violência já existente.

Esse mesmo sistema é legitimado cotidianamente pela sociedade, pela impossibilidade crítica de observar o êxito histórico da prisão em fabricar/construir um tipo específico de criminalidade, a partir de critérios sexistas, racistas e classistas (ANDRADE, 2012, p. 136) ${ }^{9}$. Então, a (ir)racionalidade da prisão, as consequências do cárcere para a sociedade e a insatisfação das vítimas diante da intervenção penal, continuam sendo problemas sem respostas satisfatórias. No entanto, a violência praticada pelo sistema penal permanece legitimada e renovada.

Apesar dos esforços mais significativos, a pena não parece encontrar o lugar de coerência no enfrentamento dos conflitos. A ideia de que "a pena não deve superar a violência informal que na sua ausência sofreria o réu pela parte ofendida ou por outras forças mais ou menos organizadas" (FERRAJOLI, 2002, p. 369) não parametriza uma forma de reação que se consubstancie em elementos objetivos, impedindo a reprodução das assimetrias sociais, como também não inviabilizando, controlando ou inibindo a vingança privada.

Muñoz Conde (2011, p. 303), embora critique o sistema penal, contrapõe-se às idéias abolicionistas e diz ser "ingênuo deduzir de tudo isso que o Direito Penal deve ser abolido,

\footnotetext{
${ }^{9} \mathrm{~A}$ autora explica: "é precisamente o funcionamento ideológico do sistema - a circulação da ideologia penal dominante entre os operadores do sistema e o senso comum ou opinião pública - que perpetua o ilusionismo, justificando socialmente a importância de sua existência e ocultando suas reais e invertidas funções. [...] a eficácia invertida significa, então, que a função latente e real do sistema não é combater (reduzir e eliminar) a criminalidade [...], mas, ao invés, construí-la seletiva e estigmatizantemente, e neste processo reproduzir, material e ideologicamente, as desigualdades e assimetrias sociais (de classe, de gênero e de raça)". (ANDRADE, 2012, p. 136)
} 
sobretudo se se leva em conta o papel que desempenha no contexto do controle social no qual está situado”. Porém, pode ser ingênuo também ignorar como o mesmo Direito Penal assume uma feição ambígua, na medida em que, além de desempenhar essas funções declaradas de controle social, acaba gerando a violência que pretende prevenir. Talvez a premissa de que a vingança pública afasta a vingança privada deva ser substituída pela premissa de que aquela alimenta o exercício das reações informais violentas, agravando as desigualdades sociais e produzindo mais violência.

\section{Considerações finais}

O estudo proposto traduz uma crítica à discussão sobre o fim (ou função) da pena que negligencia quanto à consideração da complexa questão da cifra oculta e das reações informais às condutas desviadas praticadas.

Assim como a prevenção geral, a ausência de estudos empíricos sobre a real inibição de reações informais nos permite inferir que a premissa segundo a qual a vingança pública afasta, controla e/ou inibe a vingança privada pode ser entendida como uma especulação. Não se pode sustentar uma pretensa ciência, como ocorre com o Direito Penal, a partir de especulações. Caso não se tenha, especificamente, como auferir o número de pessoas que deixaram de praticar a autotutela em razão da ameaça de pena, então não se pode afirmar que a aplicação de penas pelo Estado faz com que o cidadão não reproduza o modelo de comportamento da idade antiga, considerado como "Idade de ouro" da vítima, como outrora fora sinalizado.

A partir da dicotomização entre a vingança pública e a vingança privada, alguns fatores importantes não são observados, dentre os quais alguns são destacados: as zonas de intersecção entre os dois tipos de reação (estatal e informal); a coincidência entre os tipos de crimes que são mais perseguidos; a coincidência entre as pessoas que são mais atingidas pelo sistema penal e pelos linchamentos. Esses elementos, embora tenham aparecido no curso da investigação, não constituem objeto da presente pesquisa. No entanto, são temas que emergem deste artigo, o que pode estimular a produção de outros trabalhos.

As perspectivas teóricas analisadas no presente trabalho (garantismo e abolicionismo) apresentam leituras distintas acerca da relação existente entre a vingança pública e a vingança privada. Se o abolicionismo penal se mostra ingênuo ao ignorar as funções do Direito Penal 
para o corpo social, o garantismo penal justifica o Direito Penal em uma premissa que mereceria uma maior prudência, principalmente com estudos empíricos que pudessem sinalizar os reais motivos das reações informais. Diante desses pontos críticos, emerge ainda a necessidade de estudo sobre a maneira com a qual a sociedade assimila a violência estatal, reproduzindo-a e legitimando-a.

Por fim, essas considerações se mostram relevantes para refletir sobre outras formas menos violentas de resolução de conflitos sociais. O esforço garantista para a minimização do Direito Penal é bastante significativo nessa trajetória, assim como as críticas, que não podem ser ignoradas, formuladas pelos abolicionistas. Estes são considerados utópicos nas suas propostas de erradicação do cárcere e devolução dos conflitos para as partes. A utopia abolicionista, como algo difícil de concretizar, em alguma medida, não parece assim tão distante da ideia de que a vingança pública controlaria, inibiria ou anularia a vingança privada. A cifra oculta da criminalidade já evidencia que a não intervenção penal é a regra e não seria mesmo o sistema penal criado para administrar o volume total das condutas desviadas praticadas. Então, não parece se sustentar, em uma observação mais acurada, a noção de que a prevenção da reação informal é o escopo precípuo do Direito Penal.

\section{Referências bibliográficas}

ANDRADE, Vera Regina Pereira de Andrade. Pelas mãos da Criminologia: o controle penal para além da (des) ilusão.Rio de Janeiro: Revan, 2012.

ANDRADE, Vera Regina Pereira de. A construção social dos conflitos agrários como criminalidade. In: Rogério Dultra dos Santos. (Org.). Introdução Crítica ao Estudo do Sistema Penal, Florianópolis, 1999.

ANDRADE, Vera Regina Pereira de. A ilusão de segurança jurídica: do controle da violência à violência do controle penal.2 ${ }^{\mathrm{a}}$ Ed.Porto Alegre: Livraria do Advogado, 2003.

ANDRADE, Vera Regina Pereira de. Do paradigma etiológico ao paradigma da reação social :mudança e permanência de paradigmas criminológicos na ciência e no senso comum. Revista Brasileira de Ciências Criminais, São Paulo, n. 14, v. 4, p. 276-287, 1996.

ÁVILA, Gustavo Noronha de. O debate entre Luigi Ferrajoli e os abolicionistas: entre a sedução pelo discurso do medo e as práticas libertárias. Revista Jurídica Cesumar, maio/ago, v. 16, n. 2, p. 543-561, 2016. Disponível em:

http://periodicos.unicesumar.edu.br/index.php/revjuridica/article/view/4410 Acesso em 03 fev. 2018.

BARATTA, Alessandro. Criminologia Crítica e Crítica do Direito Penal. 3 ed. Rio de Janeiro: Editora Revan: Instituto Carioca de Criminologia, 2002.

BORGES, Thais. Justiça com as próprias mãos: Bahia registra pelo menos 45 linchamentos desde o ano passado. Jornal Correio da Bahia. Salvador, 04 de jul de 2017. Disponível em: <http://www.correio24horas.com.br/noticia/nid/justica-com-as-proprias-maos-bahia-registrapelo-menos-45-linchamentos-desde-o-ano-passado/>. Acesso em: 18 ago. 2017. 
CARVALHO, Salo de. Antimanual de Criminologia. 4 ed. Rio de Janeiro: 2011.

CHRISTIE, Nils. Limites à dor: o papel da punição na política criminal. Trad. Gustavo

Noronha de Ávila, Bruno Silveira Rigon e Isabela Alves. Belo Horizonte: Editor D’Plácido, 2017.

FERRAJOLI, Luigi. Direito e Razão: teoria do garantismo penal. 4 ed. São Paulo: Editora

Revista dos Tribunais, 2002.

HULSMAN, Louk; CELIS, Jacqueíine Bernat de. Penas Perdidas: o sistema penal em questão.Trad. Maria Lúcia Karam. 2 ed. Rio de Janeiro: LUAM, 1997.

MARTINS, José de Souza. As condições do estudo sociológico dos linchamentos no

Brasil.Disponível em:

<http://img.travessa.com.br/capitulo/CONTEXTO/LINCHAMENTOS_A_JUSTICA_POPUL AR_NO_BRASIL-9788572448918.pdf >. Acesso em: 18 ago. 2017.

MATHIESEN, Thomas. A caminho do Século XXI: abolição, um sonho possível. Verve, São Paulo, n. 4, p. 80-111, 2003.

PASSETI, Edson; SILVA, Roberto Dias. Conversações abolicionistas: uma crítica do sistema penal e da sociedade punitiva. São Paulo: IBCCRIM/PEPG Ciências Sociais PUC-SP, 1997. MOLINA, Antônio García-Pablos; GOMES, Luiz Flávio. Criminologia. 8 ed. São Paulo: Editora Revista dos Tribunais, 2012.

MUÑOZ CONDE, Francisco e HASSEMER, Winfried. Introdução à Criminologia. Rio de Janeiro: Editora Lumen Juris, 2011.

REDAÇÃO. Após matar duas pessoas, homem é linchado em festa na Bahia. Jornal Correio da Bahia. Disponível em: <http://www.correio24horas.com.br/noticia/nid/apos-matar-duaspessoas-homem-e-linchado-em-festa-na-bahia/>. Acesso em: 18/08/2017.

REDAÇÃO. Homem morre após ser espancado e baleado no Engenho Velho da Federação. Jornal Correio da Bahia. Salvador, 04 de jul de 2017. Disponível em:

http://www.correio24horas.com.br/noticia/nid/homem-morre-apos-ser-espancado-e-baleadono-engenho-velho-da-federacao/>. Acesso em: 18/08/2017.

ZAFFARONI, Eugênio Raúl e PIERANGELI, José Henrique. Manual de Direito Penal Brasileiro: parte geral. 3 ed. São Paulo: Editora Revista dos Tribunais, 2001.

ZAFFARONI, Eugênio Raul. Em busca das penas perdidas: a perda de legitimidade do sistema penal. 5 ed. Rio de Janeiro: Revan, 2001. 